\title{
Research on the Teaching of Computer-assisted English
}

\author{
Hong Zhou \\ Changsha Medical University, Changsha, Hunan, 410219
}

Keywords: Computer-assisted English; teaching innovation; research and countermeasures

\begin{abstract}
Computers have been widely used in English teaching, but English teachers have also created problems while using them. This paper discusses the problems and solutions of computer-assisted English teaching.
\end{abstract}

\section{Introduction}

The Ministry of Education promulgated the teaching requirements for college English courses (hereinafter referred to as course requirements) and proposed a multi-media multimedia teaching model based on computers and classrooms. This model is based on the rapid development of modern information technology and represents the development trend of foreign language teaching in the future. Then how is the computer developed and applied in foreign language teaching in our country? What role does the computer play in the reform of foreign language teaching in the university? This article analyzes the curriculum setting and teaching model of some colleges and universities and aims at the computer and foreign language in the new model. Some problems in curriculum integration, and put forward corresponding suggestions.

\section{Advantages of Computer-assisted English Teaching}

As long as teachers who have used multimedia to teach English have a deep understanding, the content of a lesson is several times more than what was previously taught by the blackboard. The time before a word was explained can now explain two to three. word. Students also have self-study CD-ROMs in their textbooks. Students can make in-depth previews of the CDs under the CDs so that teachers have more time to explain more extra-curricular knowledge.

Computers can make empty English teaching into graphic and literary teaching, which is enough to attract students' attention. Even students who do not like English very much have come to attend class every time for multimedia reasons. And now the computer software for English language teaching is getting more and more humanized. In the middle of the lecture, one or two small flashes or small humorous stories will be added. Even simulations of real life will create many examples to allow students to deepen their understanding of what they have learned.

At present, almost every teaching material is equipped with a light disk to learn, so that the old teacher can directly use the light disk to teach. Even if some textbooks do not have CD-ROM learning software, several teachers in the same class may study and develop a teaching courseware that integrates the wisdom of all students to facilitate everyone's use and to adopt the teaching methods of each teacher so that students will not only learn only Learn a teacher's knowledge.

\section{Computer-assisted English Teaching}

Since computer English teaching is after all a teaching method that has only emerged in recent years, it has exposed its problems while fully displaying its advantages: 1) Teachers have not fully utilized their advantages, but used them excessively. One of its functions is that, for example, teachers do not even learn how to use teaching software for demonstration teaching, monitor teaching, or even use software to ask questions to students, but simply show the courseware that others do to students and let them take notes. Afterwards, the same process is performed by switching to the next page; or just using it to put a movie, students are not allowed to participate in 
it at all. Some teachers do not even operate some of the textbooks with their own learning software, let alone develop their own software, and increase the inertia of some teachers. 2) Students did not really use the learning software. Some teachers just mentioned that they did not make use of teaching software. Of course, more students did not learn to use the software. They just used to show off their capital and they could not carry out human-computer communication. Multimedia computers do not have access to the Internet. They do not make use of the large network resource. Some schools have configured a large number of computer multimedia classrooms for evaluation purposes. However, these computers are severely aged and cannot be connected to the Internet, leaving many functions unavailable.

\section{New Model of Computer-assisted English Teaching}

In the fall of 2002, Shanghai University started a foreign language teaching reform experiment marked by six models, which made it one of the most popular schools in China. The school adopts an elective system, and the selection of various modes is determined by the students, except Mode 2 and 5, which are subject to the results of the College Entrance Examination. The students are free to change to other modes during the two years of college English.

(1) The Changpu teaching model, also known as the 21st century model, is the conventional method of college English teaching (common class). It recognizes the authoritative role of teachers in classroom teaching and emphasizes the role of language systems in mastering language acquisition. The model implements graded instruction and is conducted in the multimedia classrooms four times a week. The students' language ability is mainly improved through teacher-centered classroom teaching and practice.

(2) The fast-paced teaching model is also called the Sino-foreign cooperation model. It is taught by Chinese teachers and foreign teachers. Chinese teachers teach intensive classes (about 70 or so, multimedia classrooms) at 2 lessons per week. Foreign teachers teach small classes at 2 lessons. Speaking lessons (about 30 people, ordinary classrooms), through the complementary advantages of Chinese and foreign teachers, students' foreign language ability has been improved in all directions. This mode is based on the English score of the college entrance examination to select the preferred student, so the new student will directly attend College English Level II after entering the school.

(3) The multi-media teaching model is also called the new perspective model. It uses the New Horizons web tutorial as the main teaching material, provides the students with the teaching platform through the school LAN, uses the multimedia network teaching methods, and adopts the students' online self-study (2 hours per week) and Teachers in the classroom have targeted counseling (2 lessons per week) combined with extra-curricular self-arranged learning and online self-testing combined.

(4) The joyful teaching model uses a variety of teaching materials and teaching methods, such as: watching movies, reading novels, storytelling, acting in sketches, writing writing, etc. The focus is to guide students to self-study in each teaching session, and to train students to independently acquire Knowledge and the ability to listen, speak, read and write. 2 hours per week for the student's computer room to study independently, the teacher to give guidance; 2 hours for the teacher face counseling.

(5) The high starting point teaching mode is specially designed for the 160 freshmen before the full-year college entrance examination. The use of teaching methods and materials in the basic stage of English teaching has a high starting point and rapid progress. It also selects the Shanghai Intermediate English Interpretation Qualification Certificate Examination and matching materials to enable students participating in this model to have good oral and basic interpreting skills. This model adopts a student-centered approach to teaching and focuses on developing learners' autonomous learning ability.

(6) Sydney Industrial and Commercial ESP teaching model, mainly for the purpose of practical English teaching courses. The model was jointly taught by foreign teachers hired by the Sydney Business School and Chinese teachers from the Foreign Languages Institute. The teaching methods of small classes and modules are adopted, the content and hours of college English are reduced, 
foreign English teaching content is introduced, and infiltration teaching is conducted.

\section{Strategies of Computer-assisted English Teaching}

First of all, teachers should fundamentally change their concepts and fully recognize the important role of computers in foreign language teaching. With the rapid development of computer science, the role of computers in foreign language teaching has far exceeded its auxiliary functions. Computers have gradually moved from the auxiliary role to the teaching front. The future development trend is from auxiliary to leading. The English-based multi-media teaching model based on computer and classroom proposed by the Ministry of Education is not a computer-aided teaching mode in the general sense, but refers to the integration of computers (including information and network technology), classroom teaching and college English courses. The traditional teaching theory regards the computer as an auxiliary tool, and the integrated English course is an indispensable and organic part of the entire course, with more emphasis on the premise of making full use of the advantages of information and network technology. To give full play to the enthusiasm and creativity of teachers and students. In other words, it is necessary to integrate traditional classroom face-to-face and modern computer network learning into our English curriculum. Teachers can only actively carry out teaching activities in practice by realizing that computer networks are indispensable to foreign language teaching.

Second, teachers should reorient their roles and learn to change from a single knowledge imparter in the past to a designer, manager, and facilitator of student learning. With the increasing richness of computer network resources, teaching resources also need to be constantly updated. Therefore, teachers should use computer networks to develop and provide teaching resources for students, and design specific teaching tasks based on student characteristics to support students' meaningful knowledge building and learning. At the same time, teachers must also assume the role of managers, conduct classroom management in a real teaching environment, and coordinate and improve the entire teaching process. In other words, it is impossible for teachers to consider all the details of teaching activities. Many problems may suddenly appear. This requires teachers to coordinate and deal with them to ensure the smooth progress of teaching activities. In addition, teachers also need to act as learning facilitators. In a resource-rich e-learning environment, teachers are required to instruct students how to use online resources for learning. At the same time, they must keep abreast of their learning, actively stimulate students' thinking, and encourage students to make self-decisions. The facilitation role of teachers is also reflected in providing students with demonstrations or describing ways to solve problems, so as to ensure that students receive the necessary learning support or learning remedies during the learning process.

Computer-assisted English teaching technology is an emerging science that covers a wide range of technologies, including sound, image, word processing and many other aspects of technology. I am now at intermediate level. I am very troubled with sound and image processing in this technology. Using PowerPoint to process images has its advantages, but there are also shortcomings, no direct sound and images. The use of software such as Authware, Flash, Photo is still a blind spot for me, but it suffers from no one asking for advice. Therefore, to produce good multimedia software, it is necessary to have relevant teaching experience and teachers who can produce dual-media knowledge of multimedia software, and to increase the training of teachers, and constantly learn the use of new software from domestic and foreign famous schools. Make computer-assisted English teaching software use a higher level of efficiency. It is necessary to educate students to learn more computer knowledge and inform them of the importance of computer software use or even production. From time to time some assignments in this area or competitions in this area increase students' awareness of the importance of computers, and can even absorb some students' access to English learning software is being produced, multimedia, local area network teaching hardware and software If teachers are not learning or making full use of multimedia because of inertia, then the main reason for students is that they do not have a computer for their use, their computer learning. Where do you talk about? Schools should provide them with sufficient conditions to enable students to buy useful computers, or schools that provide specialized areas for 
students to learn and use learning software. They can provide teachers and students with a complete local area network. The exchange platform between masters and students increases feedback between teachers and students. This will be one of the most critical hardware facilities for bringing computers into classrooms, entering schools, and improving teaching efficiency.

\section{Conclusion}

The use of computer media in English teaching has given fresh input to our teaching work, which has greatly improved the efficiency of classroom teaching and opened the way for innovative education. In future work, we should use more brains to explore more uses of computers, make full use of the teaching functions of the campus computer network, give full play to the advantages of modern education technology, serve our modern English teaching, reform English teaching, and explore new Teaching mode provides a new way.

\section{References}

[1] Mo Jinguo, et al. New model of college English teaching integrated with foreign language education technology [J]. China Electrification Education, 2007, 1.

[2] Chai Shaoming et al. On Language Learning Center and the Cultivation of Autonomous Learning Ability [J]. Modern Educational Technology, 2006, 4.

[3] Chen Jianlin. From Assistant to Dominant: New Trends in the Development of Computer Foreign Language Teaching [J]. Foreign Languages in Electrotechnics, 2005, 4.

[4] Chen Jianlin. Organic integration of computer networks and foreign language courses under the new model of college English teaching: An ecological survey of the concept of computer-assisted foreign language teaching [J]. Foreign Languages and Audio-Visual Teaching, 2006, 6.

[5] Feng Qi, et al. Innovative ideas, deepening reforms: College English multi-mode teaching experiment [J]. Foreign language and electrification teaching, 2005, 5. 